\title{
Pengaruh Penambahan Abu Cangkang Kelapa Sawit Pada Tanah Lempung Paccinongang Kabupaten Gowa
}

\author{
Leonard Felix Widyo Sanderan*1, Irwan Lie Keng Wong ${ }^{\star 2}$, Monika Datu Mirring Palinggi³ \\ *1 Mahasiswa Program Studi Teknik Sipil, Universitas Kristen Indonesia Paulus, Makassar \\ Email leonardfelix37@gmail.com \\ *2 Dosen Program Studi Teknik Sipil, Universitas Kristen Indonesia Paulus, Makassar \\ Email irwanliekengwong@gmail.com \\ *3 Dosen Program Studi Teknik Sipil, Universitas Kristen Indonesia Paulus, Makassar \\ Email monikadatumirring@gmail.com
}

\begin{abstract}
ABSTRAK
Tanah memiliki peran penting dalam suatu perencanaan konstruksi jalan raya yang berfungsi meneruskan beban dari lapisan atas, tetapi tidak selamanya lapisan tanah dasar mampu berfungsi dengan baik. Oleh karena itu pada penelitian ini dilakukan untuk mengetahui pengaruh penambahan abu cangkang kelapa sawit pada tanah lempung terhadap UCT (Unconfined Compression Test). Jenis tanah yang akan digunakan untuk penelitian ini adalah tanah lempung yang diambil pada daerah Paccinongang, Kabupaten Gowa. Metodologi dalam penelitian ini dilakukan beberapa pengujian sifat fisik tanah kemudian pengujian Kompaksi untuk mendapatkan nilai kadar air optimum, dan pengujian Kuat Tekan Bebas (Unconfined Compression Test) untuk mendapatkan nilai kuat tekan (qu). Hasil penelitian yang dilakukan menunjukkan bahwa tanah memenuhi sifat fisik tanah lempung. Dari pengujian Kuat Tekan Bebas pada kadar abu cangkang kelapa sawit $0 \%, 3 \%, 6 \%, 9 \%, 12 \%$ dan $15 \%$ pada titik 1 nilai kuat tekan bebas menurun dari $0 \%$ sebesar $0,362 \%$ dan meningkat pada $9 \%$ sebesar $0,424 \%$. Sedangkan pada titik 2 mengalami penurunan pada $0 \%$ yaitu sebesar 0,445\% dan meningkat pada 12\% sebesar 0,423\%. Dari pengujian Kuat Tekan Bebas (Unconfined Compression Test) pada tanah lempung Paccinongang, Kabupaten Gowa dengan penambahan abu cangkang kelapa sawit dari kedua sampel terjadi peningkatan pada penambahan $9 \%$ dan $12 \%$ dari tanah lempung normal.
\end{abstract}

Kata kunci: Pengujian Kompaksi, Kuat Tekan Bebas, Paccinongang

\section{ABSTRACT}

Soil has an important role in a highway construction planning that serves to pass the load from the top layer, but not always the basic soil layer is able to function properly. Therefore, in this study was conducted to find out the effect of the addition of oil palm shell ash on clay soil to UCT (Unconfined Compression Test). The type of soil that will be usedfor penelitian is clay soil taken in Paccinongang area, Gowa Regency. The methodology in this study conducted several soil physical properties testing then Kompaksi testing to obtain optimum moisture content value, and Unconfined Compression Test to get strong press value (qu). The results of the study showed that the soil meets the physical properties of clay soil. From The Free Press Strong test on the ash content of the palm shell $0 \%, 3 \%, 6 \%, 9 \%, 12 \%$ and $15 \%$ at point 1 the free press strength value decreased from $0 \%$ by $0.362 \%$ and increased at $9 \%$ by $0.424 \%$. Meanwhile, at point 2 , it decreased by $0 \%$ by $0.445 \%$ and increased at $12 \%$ by $0.423 \%$. From the Unconfined Compression Test on Paccinongang clay, Gowa Regency with the addition of oil palm shell ash from both samples, there was an increase in the addition of $9 \%$ and $12 \%$ of normal clay soil.

Keywords: Standar Proctor, Unconfined Compression Test, Paccinongan

\section{PENDAHULUAN}

Tanah didefenisikan sebagai material yang terdiri dari agregat (butiran) mineral-mineral padat yang tidak tersementasi (terikat secara kimia) satu sama lain. [1] Tanah lempung adalah tanah yang berbutir halus, yang memiliki sifat kohesif dan plastis. [2] Stabilisasi tanah merupakan salah satu cara memperbaiki kondisi tanah. [3]
Bahan alternatif untuk stabilisasi tanah yaitu pemanfaatan abu cangkang sawit yang berasal dari limbah padat Pabrik Pengolahan Kelapa Sawit yang jumlahnya terus meningkatdan belum termanfaatkan dengan baik. [4]

Pemadatan adalah peristiwa bertambahnya berat volume kering oleh beban dinamis. [5] Tujuan pemadatan adalah untuk memperbaiki sifat-sifat teknis massa tanah yaitu menaikkan kekuatannya, 
Paulus Civil Engineering Journal

Jurnal Teknik Sipil UKI-Paulus Makassar

https://doi.org/10.52722/pcej.v3i2.3210

memperkecil pemamptannya dan daya rembes airnya, seta memperkecil pengaruh air terhadap tanah. [6] Salah satu parameter yang dipakai untuk menentukan kekuatan geser tanah adalah pengujian kuat tekan bebas tanah (Unconfined Compression Test. [7]

Tujuan dari penelitian ini adalah untuk mengetahui sifat fisik tanah asli dari Paccinongang Kabupaten Gowa dan mengetahui pengaruh penambahan abu cangkang kelapa sawit pada tanah lempung terhadap hasil uji kuat tekan bebas (Unconfined Compression Tes).

\section{METODE}

Penelitian ini dilakukan mulai dari pengambilan sampel tanah di Paccinongang, Kabupaten Gowa dan pengambilan cangkang kelapa sawit di Pabrik Kelapa Sawit PT. Surya Raya Lestari II, Kecamatan Budong-budong, Kabupaten Mamuju Tengah pada bulan Juni 2020. Untuk proses pengujian sifat fisik tanah dan pencampuran serta pengujian pemadatan dilakukan pada bulan Juli-September 2020 di Laboratorium Mekanika Tanah, Program Studi Teknik Sipil, Fakultas Teknik, Universitas Kristen Indonesia Paulus Makassar.

\section{A. Lokasi Pengambilan Sampel Tanah dan Persiapan Bahan}

Lokasi pengambilan bahan sampel tanah terdapat di Paccinongang, Kabupaten Gowa dan cangkang kelapa sait terletak di Pabrik Kelapa Sawit PT Surya Lestari II, Kecamatan Budong-Budong, Kabupaten Mamuju Tengah.

\section{Volume 3 No.2, Juni 2021 \\ e-ISSN 2775-4529 \\ p-ISSN 2775-8613}

\section{B. Pemeriksaan Karakteristik Tanah}

Pengujian karakteristik tanah dilakukan sesuai dengan metode ASTM (American Standar Testing And Material). Pengujian tersebut antara lain :Uji kadar air (ASTM D-2216), Uji berat jenis (ASTM 854-58), Uji Batas-Batas Atterberg (ASTM D 431895), dan Uji Analisa Butiran (ASTM D 422-72) dan (ASTM D 1140-54).

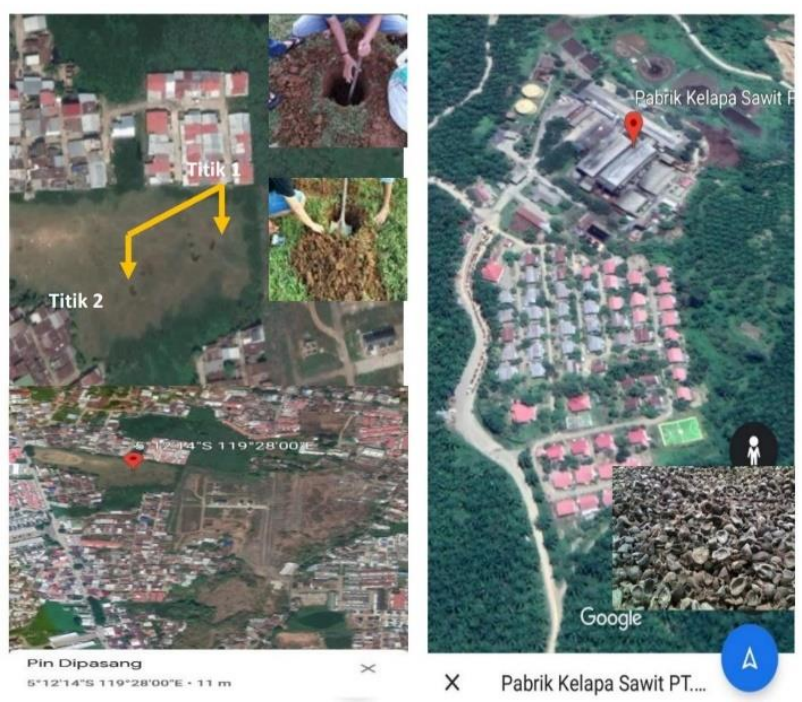

Gambar 1. Lokasi pengambilan sampel tanah dan pengambilan cangkang kelapa sawit

\section{Rancangan Benda Uji}

Rancangan benda uji pada tanah adalah untuk mengetahui jumlah sampel benda uji yang akan digunakan dalam penelitian ini dapat dilihat pada tabel. 1

Tabel 1. Rancangan benda uji

\begin{tabular}{ccccccc}
\hline No & Benda Uji & \multicolumn{2}{c}{ Tambahan kadar abu } & \multicolumn{2}{c}{ Sampel } & Jumlah Benda Uji \\
& & $(\%)$ & gr & I & II & \\
\hline 1 & Kadar air & - & - & 3 & 3 & 6 \\
2 & Berat Jenis & - & - & 2 & 2 & 4 \\
3 & Gradasi & - & - & 1 & 1 & 2 \\
4 & Batas-batas Atterberg & - & - & & & \\
& Batas Cair & - & - & 4 & 4 & 4 \\
& Batas Susut & - & - & 2 & 2 & 6 \\
5 & Batas Plastis & - & - & 3 & 3 & 10 \\
& Kompaksi & 0 & 0 & 5 & 5 & 10 \\
& & 3 & 90 & 5 & 5 & 10 \\
& & 6 & 180 & 5 & 5 & 10 \\
& & 9 & 270 & 5 & 5 & 10
\end{tabular}


Paulus Civil Engineering Journal Jurnal Teknik Sipil UKI-Paulus Makassar https://doi.org/10.52722/pcej.v3i2.3210

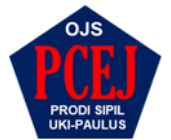

Volume 3 No.2, Juni 2021 e-ISSN 2775-4529 p-ISSN 2775-8613
6

$\begin{array}{cc}\text { Kuat Tekan Bebas } & 15 \\ \text { (UCT) } & 0 \\ & 3 \\ & 6 \\ & 9 \\ & 12 \\ & 15\end{array}$

15

0

$3 \quad 90$

$6 \quad 180$

$9 \quad 270$

$12 \quad 360$

15
450

0

90

180

360

450

\section{5}

1

1

1

1

1

1 optimum dan mengetahui kuat tekan pada tanah dapat dilihat pada tabel 2 dibawah ini.

Pengujian pada tanah adalah untuk mengetahui sifat fisik pada tanah, menentukan kadar air

Tabel 2. Pengujian sampel

\begin{tabular}{clc}
\hline No & \multicolumn{1}{c}{ Pengujian } & Jumlah Benda Uji \\
\hline 1 & Pengujian kadar air tanah asli & 6 \\
2 & Pengujian berat jenis & 4 \\
3 & Pengujian gradasi & 2 \\
4 & Pengujian batas-batas atterberg & \\
& Pengujian Batas Cair (Liquid Limit) & 8 \\
& Pengujian Batas Susut (Plastic Limit) & 4 \\
& Pengujain Batas Plastis ( Shrinkage Limit) & 6 \\
5 & Pengujian Kompaksi ( Standard Proctor) & 60 \\
6 & Pengujain UCT ( Unconfined Compression Test) & 12 \\
\hline
\end{tabular}

HASIL DAN PEMBAHASAN

Dari hasil pengujian sifat fisis tanah yang dilakukan didapatkan hasil masing-masing percobaan sebagai berikut:

\section{Hasil Pengujian Sifat Fisik Tanah}

Tabel 3. Rekapitulasi hasil pengujian sifat fisik tanah

\begin{tabular}{|c|c|c|c|c|}
\hline No & \multicolumn{3}{|c|}{ Sampel 1} & Nilai \\
\hline 1 & \multicolumn{2}{|c|}{ Kadar Air (w) } & $\%$ & 35,32 \\
\hline 2 & \multicolumn{2}{|c|}{ Berat Jenis (Gs) } & $\mathrm{gr} / \mathrm{cm}^{3}$ & 2,59 \\
\hline \multirow{5}{*}{3} & \multirow{5}{*}{ 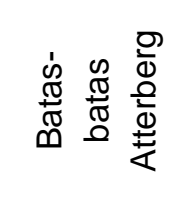 } & Batas Cair (Liquid Limit) & $\%$ & 48,3 \\
\hline & & Batas Plastis (Plastic Limit) & $\%$ & 34,26 \\
\hline & & Batas Susut (Shrinkage Limit) & $\%$ & 6,11 \\
\hline & & Indeks Plastisitas (Plasticity Index) & $\%$ & 14,04 \\
\hline & & Persen Lolos Saringan No.200 & $\%$ & 92,76 \\
\hline \multirow{4}{*}{4} & \multirow{4}{*}{$\begin{array}{l}\bar{w} \\
\frac{\pi}{0} \\
\bar{\pi} \\
\overline{0}\end{array}$} & Gravel (G) & $\%$ & 0 \\
\hline & & Sand (S) & $\%$ & 7,238 \\
\hline & & Silt (M) & $\%$ & 64,556 \\
\hline & & Clay $(\mathrm{C})$ & $\%$ & 28,206 \\
\hline \multirow{2}{*}{ No } & \multicolumn{3}{|c|}{ Sampel 2} & \\
\hline & \multirow{2}{*}{\multicolumn{2}{|c|}{ Pemeriksaan }} & & Nilai \\
\hline 1 & & & $\%$ & 35,89 \\
\hline 2 & \multicolumn{2}{|c|}{ Berat Jenis (Gs) } & $\mathrm{gr} / \mathrm{cm}^{3}$ & 2,59 \\
\hline \multirow{4}{*}{3} & \multirow{4}{*}{ 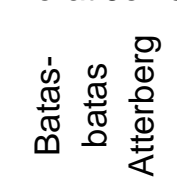 } & Batas Cair (Liquid Limit) & $\%$ & 54,03 \\
\hline & & Batas Plastis (Plastic Limit) & $\%$ & 40,63 \\
\hline & & Batas Susut (Shrinkage Limit) & $\%$ & 8,60 \\
\hline & & Indeks Plastisitas (Plasticity Index) & $\%$ & 13,40 \\
\hline
\end{tabular}




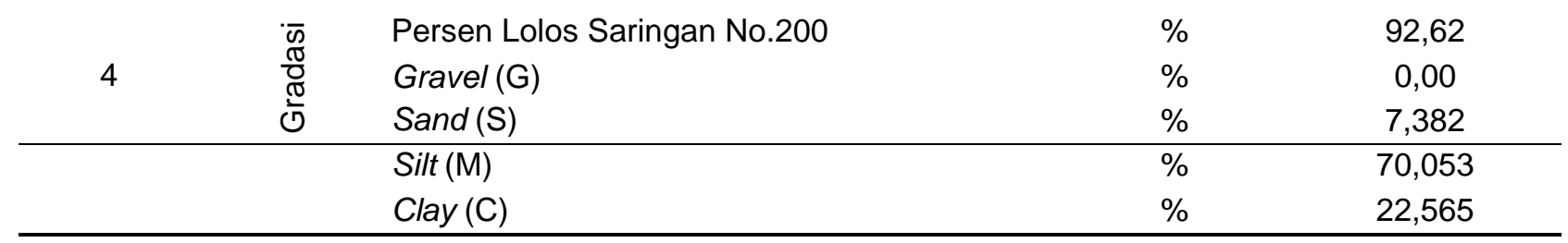

Tabel 4. Rekapitulasi rata-rata hasil pengujian sifat fisik tanah

\begin{tabular}{|c|c|c|c|c|}
\hline No & & Rata - rata & & Nilai \\
\hline 1 & \multicolumn{2}{|c|}{ Kadar Air (w) } & $\%$ & 35,60 \\
\hline 2 & \multicolumn{2}{|c|}{ Berat Jenis (Gs) } & $\mathrm{gr} / \mathrm{cm}^{3}$ & 2,59 \\
\hline \multirow{4}{*}{3} & \multirow{4}{*}{ 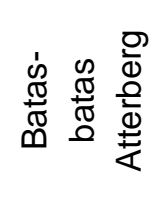 } & & $\%$ & 51,17 \\
\hline & & $\begin{array}{l}\text { Batas Cair (Liquid Limit) } \\
\text { Batas Plastis (Plastic Limit) }\end{array}$ & $\%$ & 37,45 \\
\hline & & Batas Susut (Shrinkage Limit) & $\%$ & 7,35 \\
\hline & & Indeks Plastisitas (Plasticity Index) & $\%$ & 13,72 \\
\hline & & Persen Lolos Saringan No.200 & $\%$ & 92,69 \\
\hline \multirow{4}{*}{4} & \multirow{4}{*}{$\begin{array}{l}\bar{y} \\
\frac{\pi}{0} \\
\frac{\pi}{\pi} \\
\bar{N}\end{array}$} & Gravel (G) & $\%$ & 0,00 \\
\hline & & Sand $(S)$ & $\%$ & 7,31 \\
\hline & & Silt (M) & $\%$ & 67,30 \\
\hline & & Clay $(\mathrm{C})$ & $\%$ & 25,39 \\
\hline
\end{tabular}

Hasil analisis karakteristik tanah :

a. Pengujian Kadar air (ASTM D-216)

Pengujian kadar air tanah asli didapatkan nilai kadar air yang terkandung pada titik 1 sebesar $35,32 \%$, titik 2 sebesar $35,89 \%$ dan rata-ratanya $35,60 \%$.

b. Pengujian Berat Jenis Tanah (ASTM D 854-58)

Dari pengujian berat jenis tersebut didapatkan nilai berat jenis pada titik 1 yaitu $2,59 \mathrm{gr} / \mathrm{cm}^{3}$, titik 2 yaitu $2,59 \mathrm{gr} / \mathrm{cm}^{3}$ dan rata-ratanya $2,59 \mathrm{gr} / \mathrm{cm}^{3}$. Angka ini menunjukkan tanah yang telah diteliti termasuk dalam golongan tanah lempung organik.

c. Pengujian Batas-Batas Atterberg (ASTM 431895)

Hasil pengujian batas-batas Atterberg pada sampel tanah asli yang telah diteliti di laboratorium mekanika tanah pada pengujian batas acair, batas plastis dan batas susut dapt dilihat pada tabel 5 berikut ini :

Tabel 5. Hasil pengujian batas-batas Atterberg tanah asli

\begin{tabular}{cccc}
\hline & LL & PL & IP \\
\hline Titik 1 & 48,30 & 34,26 & 14,04 \\
Titik 2 & 54,03 & 40,63 & 13,40 \\
Rata-rata & 51,165 & 37,445 & 13,72 \\
\hline
\end{tabular}

d. Pengujian Analisa Saringan (ASTM 422-72) dan Hidrometer (ASTM D 1140-54)

Hasil pengujian yang diperoleh dari perhitungan analisa saringan yaitu nilai persen lolos tiap-tiap saringan yang kemudian dihubungkan dengan diameter saringan sehingga terbentuk sebuah garis yang menandakan bahwa sekian persen tanah berpasir yang diperoleh. Setelah itu pada analisa hydrometer, diperoleh diameter butir dari pada tanah dan persentase kehalusannya. Kedua hal tersebut lalu dihubungkan pada titik koordinat tiap diameter saringan kemudian menghaslkan bahwa sekian persen tanah yang tergolong lanau dan empung. Perolehan tanah berpasir, berlanau dan berlempung bila kita lihat dari Grafik yaitu :

Titik 1
a) Pasir : :100\%-92,762\% $=7,238 \%$
b) Lanau : $92,762 \%-28,206 \%=64,556 \%$
c) Lempung : $100 \%-(92,762 \%+7,238 \&)=$ $28,206 \%$

Titik 2
a) Pasir : :100\%-92,618\% $=7,382 \%$
b) Lanau : $92,612 \%-22,565 \%=70,053 \%$
c) Lempung : $100 \%-(92,762 \%+7,382 \%)=$ $22,565 \%$

\section{Hasil Pengujian Kompaksi (Standard Proctor)}


Dari hasil pengujian kompaksi yang telah dilajukan didapatkan hasil pada Tabel 6 sebagai berikut :

Tabel 6 : Hasil perhitungan pemadatan titik 1 variasi $0 \%$

\begin{tabular}{|c|c|c|c|c|c|c|}
\hline & & $3 \mathrm{~kg}+680 \mathrm{ml}$ & $3 \mathrm{~kg}+730 \mathrm{ml}$ & $3 \mathrm{~kg}+780 \mathrm{ml}$ & $3 \mathrm{~kg}+830 \mathrm{ml}$ & $3 \mathrm{~kg}+880 \mathrm{ml}$ \\
\hline \multicolumn{7}{|l|}{ Berat Mold + Tanah } \\
\hline Basah & $\mathrm{Gr}$ & 6370 & 6390 & 6420 & 6410 & 6398 \\
\hline Berat Mold & $\mathrm{Gr}$ & 4900 & 4900 & 4900 & 4900 & 4900 \\
\hline \multicolumn{7}{|l|}{ Berat Tanah } \\
\hline Basah & $\mathrm{Gr}$ & 1470 & 1490 & 1520 & 1510 & 1498 \\
\hline $\begin{array}{l}\text { Volume Mold ( } r= \\
5.05, t=16,7)\end{array}$ & & 1337,978 & 1337,978 & 1337,978 & 1337,978 & 1337,978 \\
\hline Kepadatan & & 1,099 & 1,114 & 1,136 & 1,129 & 1,120 \\
\hline Kepadatan Kering & & 0,905 & 0,912 & 0,919 & 0,907 & 0,891 \\
\hline $\begin{array}{l}\text { Berat cawan + } \\
\text { Tanah Basah }\end{array}$ & $\mathrm{Gr}$ & 8,643 & 7,739 & 7,823 & 8,608 & 9,823 \\
\hline $\begin{array}{l}\text { Berat cawan + } \\
\text { Tanah Kering }\end{array}$ & $\mathrm{Gr}$ & 7,290 & 6,507 & 6,511 & 7,123 & 8,010 \\
\hline Berat cawan & $\mathrm{Gr}$ & 0,92 & 0,94 & 0,92 & 0,94 & 0,92 \\
\hline Berat Tanah Basah & $\mathrm{Gr}$ & 7,723 & 13,617 & 16,728 & 15,084 & 13,656 \\
\hline Berat Tanah Kering & Gr & 6,370 & 11,217 & 13,679 & 12,281 & 11,051 \\
\hline Berat Air & $\mathrm{Gr}$ & 1,353 & 2,400 & 3,049 & 2,803 & 2,605 \\
\hline Kadar air & $\%$ & 21,412 & 22,044 & 23,577 & 24,393 & 25,654 \\
\hline $\mathrm{ZAV}=\mathrm{Gs} /(1+\mathrm{W} / 100$ & Gs) & 1,662 & 1,604 & 1,552 & & \\
\hline
\end{tabular}

Tabel 7. Data untuk konversi ke grafik kompaksi titik variasi $0 \%$

\begin{tabular}{ccc}
\hline $\begin{array}{c}\text { Kadar air } \\
\text { optimum } \\
(\%)\end{array}$ & $\begin{array}{c}\text { Kepadatan } \\
\text { Kering } \\
\text { maksimum } \\
\left(\mathrm{Gr} / \mathrm{cm}^{3}\right)\end{array}$ & ZAV \\
\hline 21,412 & 0,905 & 1,662 \\
22,044 & 0,912 & 1,645 \\
22,577 & 0,919 & 1,604 \\
24,393 & 0,907 & 1,583 \\
25,654 & 0,891 & 1,552 \\
\hline
\end{tabular}

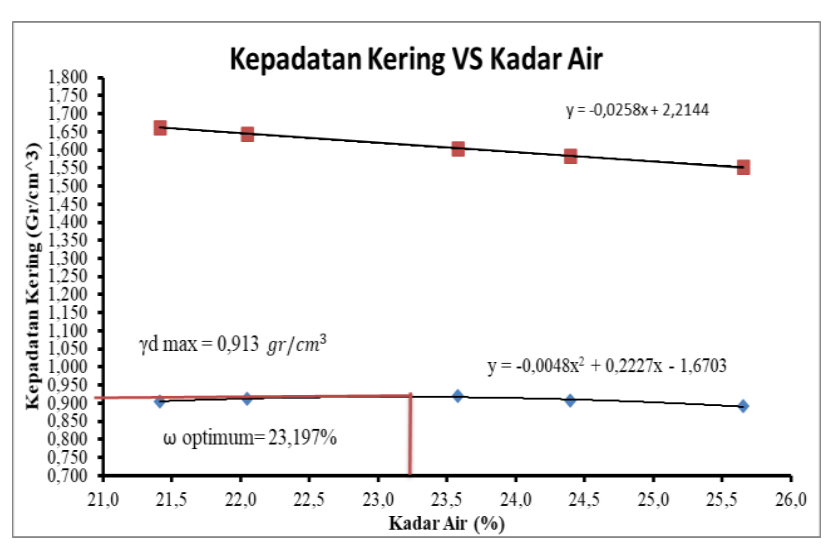

Gambar 2. Grafik kompaksi (standard proctor) titik 1 variasi $0 \%$

Secara grafik, nilai kadar air optimum serta kepadatan kering, diperoleh dengan meihat dimana puncak dari parabola yang dihasilkan dari grafik hubungan kadar air dan kepadatan kering, lalu dapat ditarik garis lurus secara vertical serta horizontal dari top parabola tersebut, sehingga menghasilkan nilai untuk kadar air optimum sebesar $23,262 \%$ dan kepadatan kering $0,931 \mathrm{gr} / \mathrm{cm}^{3}$.

Sedangkan secara analisis, nilai untuk kadar air optimum dan kepadatan kering diperoleh dari persamaan linear yang dihasilkan dari grafik diatas, yaitu:

a. Untuk hubungan antara Kadar Air $(\omega)$ dengan ZAV (Zero Air Void), diperoleh persamaan :

$\mathrm{ZAV}=-0,0258 \omega+2,2441$

$\mathrm{ZAV}=-0,00258 \omega+2,2441$

Saat $\mathrm{ZAV}=0$, maka :

$$
\begin{aligned}
0 & =-0,00258 \omega+2,2441 \\
0,0258 & =2,2441 \\
\omega & =2,2441 / 0,0258 \\
\omega & =85,829 \%
\end{aligned}
$$


Paulus Civil Engineering Journal

Jurnal Teknik Sipil UKI-Paulus Makassar

https://doi.org/10.52722/pcej.v3i2.3210

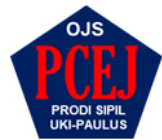

Volume 3 No.2, Juni 2021

e-ISSN 2775-4529

p-ISSN 2775-8613
Sedangkan maksud dari ZAV $100 \%$ menunjukkan bahwa kondisi pori-pori tanah sudah tidak mengandung udara lagi. Diperoleh hasil dari persamaan di atas adalah $85,829 \%$ sedangkan maksud dari ZAV $100 \%$ menunjukkan bahwa kondisi pori-pori tanah sudah tidak mengandung udara lagi. Diperoleh hasil dari persamaan di atas adalah $85,829 \%$ sehingga dapat diketahui bahwa masih terdapat udara dalam pori-pori pada tanah.

b. Untuk hubungan antara Kadar Air $(\omega)$ dengan Kepadatan Kering $(\gamma$ dry $)$, diperoleh persamaan : $\gamma_{\mathrm{dry}}=-0,0042 \omega^{2}+0,1954 \omega-1,3411$

Turunan pertama dari pers. $\gamma$ dry merupakan garis singgung

$$
\begin{aligned}
\frac{\partial \gamma_{d r y}}{\partial \omega}=-0,008 \omega+0,1957 \\
\omega_{\text {opt }} \text { diperoleh saat } \frac{\partial \gamma_{d r y}}{\partial \omega}=0 \\
\frac{\partial \gamma_{d r y}}{\partial \omega}=0, \text { maka } 0,0084 \omega_{\text {opt }}=0,1954 \\
\omega_{\mathrm{opt}}=0,1954 / 0,0084 \\
\omega_{\mathrm{opt}}=23,262 \%
\end{aligned}
$$

Dari grafik diperoleh :

$$
\begin{aligned}
\omega_{\mathrm{opt}}= & 23,262 \% \\
\gamma_{\mathrm{dry}}= & -0,0042 \omega^{2}+0,1954 \omega-1,3411 \\
\gamma_{\text {dry }}= & \left(-0,0042(23,262)^{2}\right)(0,1954(23,262)) \\
& 1,3411 \\
\gamma_{\text {dry }}= & -2,2727+4,54539-1,3411 \\
\gamma_{\text {dry }}= & 0,931 \mathrm{gr} / \mathrm{cm}^{3}
\end{aligned}
$$

Hasil pengujian kompaksi pada titik 2

Tabel 7 : Hasil perhitungan pemadatan titik 2 variasi $0 \%$

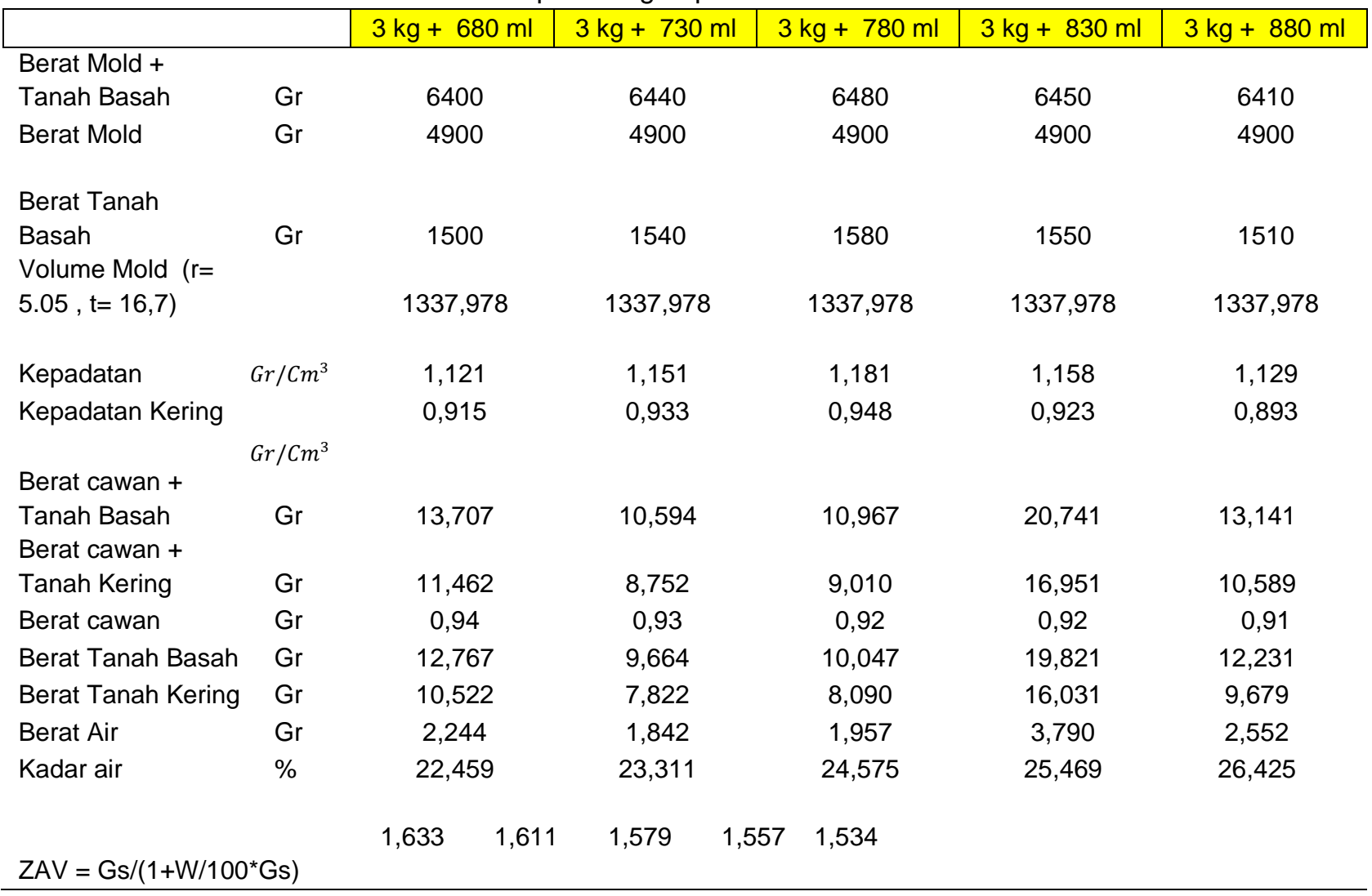

Tabel 9. Data untuk konversi ke grafik kompaksi titik 2 variasi $0 \%$

\begin{tabular}{ccc}
\hline $\begin{array}{c}\text { Kadar air optimum } \\
(\%)\end{array}$ & Kepadatan Kering maksimum $\left(\mathrm{gr} / \mathrm{cm}^{3}\right)$ & ZAV \\
\hline 22,459 & 0,915 & 1,633 \\
23,311 & 0,933 & 1,611 \\
24,575 & 0,948 & 1,579 \\
25,469 & 0,923 & 1,557 \\
26,425 & 0,893 & 1,534 \\
\hline
\end{tabular}


Paulus Civil Engineering Journal

Jurnal Teknik Sipil UKI-Paulus Makassar

https://doi.org/10.52722/pcej.v3i2.3210

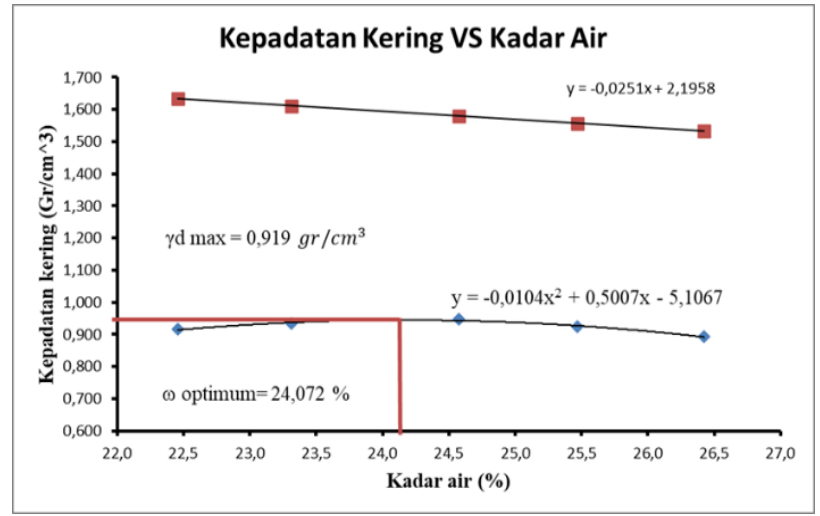

Gambar 3. Grafik kompaksi (Standard Proctor) titik 2 variasi $0 \%$

Secara grafik, nilai kadar air optimum serta kepadatan kering, diperoleh dengan melihat dimana titik puncak dari parabola yang dihasilkan dari grafik hubungan kadar air dan kepadatan kering, lalu dapat ditarik garis lurus secara vertical serta horizontal dari titik puncak dari parabola tersebut, sehingga menghasilkan nilai untuk kadar air optimum sebesar $24,072 \%$ dan kepadatan kering $0,919 \mathrm{gr} / \mathrm{cm}^{3}$.

Sedangkan secara analisis, nilai untuk kadar air optimum dan kepadatan kering diperoleh dari persamaan linear yang dihasilkan dari grafik diatas, yaitu:

a. Untuk hubungan antara kadar air $(\omega)$ dengan ZAV (Zero Air Void), diperoleh persamaan :

$$
\begin{aligned}
& Z A V=-0,0251 \omega+2,1958 \\
& Z A V=-0,0251 \omega+2,1958
\end{aligned}
$$

Saat $Z A V=0$, maka :

$$
\begin{aligned}
0 & =-0,0251 \omega+2,1958 \\
0,0251 \omega & =2,1958 \\
\omega & =2,1958 / 0,0251 \\
\omega & =87,482 \%
\end{aligned}
$$

Sedangkan maksud dari ZAV $100 \%$ menunjukkan bahwa kondisi pori-pori tanah sudah tidak mengandung udara lagi. Diperoleh hasil dari persamaan di atas adalah 87,482 sedangkan maksud dari ZAV 100\% menunjukkan bahwa kondisi pori-pori tanah sudah tidak mengandung udara lagi. Diperoleh hasil dari persamaan di atas adalah $87,482 \%$ sehingga dapat diketahui bahwa udara dalam pori-pori pada tanah masih ada.

b. Untuk hubungan antara Kadar Air $(\omega)$ dengan Kepadatan Kering $\left(\gamma_{\text {dry }}\right)$, diperoleh persamaan :
Volume 3 No.2, Juni 2021

e-ISSN 2775-4529

p-ISSN 2775-8613

$$
\gamma_{\text {dry }}=-0,0104 \omega^{2}+0,5007 \omega-5,1067
$$

Turunan pertama dari pers. $\gamma$ dry merupakan garis singgung

$$
\frac{\partial \gamma_{d r y}}{\partial \omega}=-0,0208 \omega+0,5007
$$

$\omega_{\mathrm{opt}}$ diperoleh saat $\frac{\partial \gamma_{d r y}}{\partial \omega}=0$

$$
\begin{aligned}
& \frac{\partial \gamma_{d r y}}{\partial \omega}=0, \text { maka } 0,0208 \omega_{\text {opt }}=0,5007 \\
& \omega_{\text {opt }}=0,5007 / 0,0208 \\
& \omega_{\text {opt }}=24,072 \%
\end{aligned}
$$

Dari grafik diperoleh :

$$
\begin{aligned}
& \omega_{\text {opt }}= 24,072 \% \\
& \gamma_{\text {dry }}=-0,0104 x^{2}+0,5007 x-5,1067 \\
& \gamma_{\text {dry }}=\left(-0,0104\left(24,072^{2}\right)\right)+(0,5007(24,072))- \\
& \quad 5,1067 \\
& \gamma_{\text {dry }}=-6,0263+12,0528-5,1067 \\
& \gamma_{\text {dry }}= 0,919 \mathrm{gr} / \mathrm{cm}^{3}
\end{aligned}
$$

\section{Hasil Pengujian Kompaksi dengan penambahan Abu Cangkang Kelapa Sawit}

Dari hasil pengujian kompaksi dengan penambahan abu cangkang kelapa sawit yang telah dilakukan diperolehan hasil pengujian kadar air optimum $\left(w_{o p t}\right), \gamma_{d}$ dan ZAV dengan perhitungan dapat dilihat pada tabel 10 :

Tabel 10. Rekapitulasi hasil pengujian pemadatan tanah (Standard Proctor)

\begin{tabular}{ccc}
\hline Abu Cangkang Kelapa & \multicolumn{2}{c}{ Kepadatan Kering } \\
Sawit & Sampel 1 & Sampel 2 \\
\hline $0 \%$ & 0,913 & 0,920 \\
$3 \%$ & 0,947 & 0,939 \\
$6 \%$ & 0,972 & 0,971 \\
$9 \%$ & 0,891 & 0,931 \\
$12 \%$ & 0,931 & 0,874 \\
$15 \%$ & 0,935 & 0,911 \\
\hline
\end{tabular}

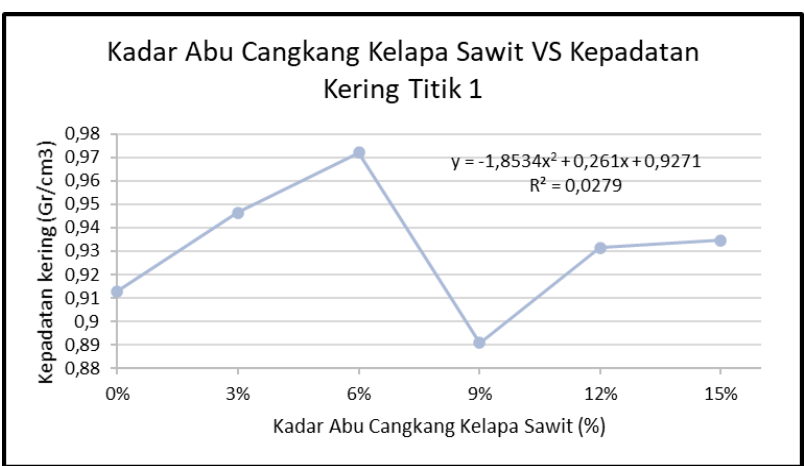

Gambar 4. Grafik hubungan abu cangkang kelapa sawit dan kepadatan kering Pada titik 1 


\section{Paulus Civil Engineering Journal}

Jurnal Teknik Sipil UKI-Paulus Makassar

https://doi.org/10.52722/pcej.v3i2.3210

Pada titk 1 Penambahan abu cangkang kelapa sawit dengan tanah menunjukkan nilai kepadatan kering berbanding lurus pada $0 \%$ hingga $6 \%$ kadar abu cangkang kelapa sawit dan mengalami penurunan pada $9 \%, 12 \%$, dan $15 \%$ sehingga $3 \%$ dan $6 \%$ yang dapat digunakan karena $6 \%$ merupakan kepadatan kering yang maksimum.

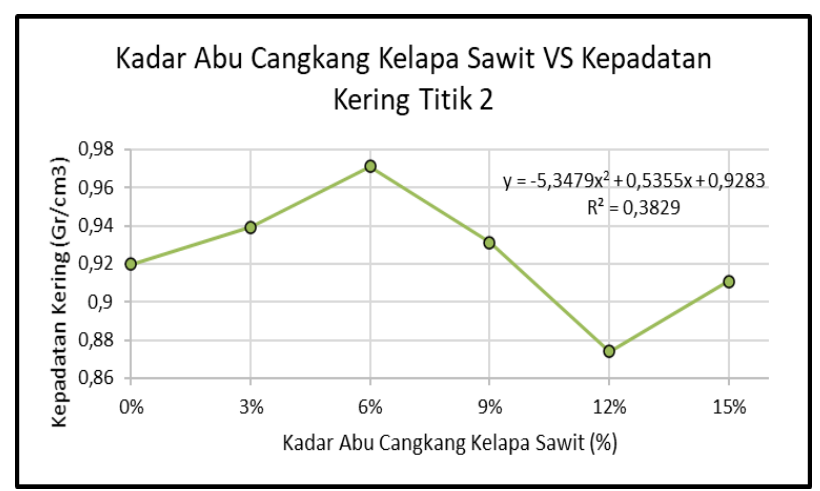

Gambar 5. Grafik abu cangkang kelapa sawit terhadap kepadatan kering titik 2

Pada titik 2 penambahan abu cangkang kelapa sawit dengan tanah menunjukkan nilai kepadatan kering berbanding lurus pada $0 \%-6 \%$ abu cangkang kelapa sawit dan turun pada $9 \%-15 \%$. Hal ini menandakan bahwa tanah pada titik 2 juga mengalami peningkatan saat ditambahkan dengan abu cangkang kelapa sawit dengan persentase $3 \%$ dan $6 \%$, karena $6 \%$ merupakan kepadatan kering yang maksimum.

\section{Hasil Pengujian Kuat Tekan Bebas (Unconfined Compression Test)}

Tabel 11. Rekapitulasi hasil pengujian kuat tekan bebas

\begin{tabular}{cccc}
\hline $\begin{array}{c}\text { Campuran Abu } \\
\text { cangkang } \\
\text { kelapa sawit }\end{array}$ & Sampel 1 & Sampel 2 & $\begin{array}{c}\text { Rata- } \\
\text { Rata }\end{array}$ \\
\hline $0 \%$ & 0,362 & 0,445 & 0,584 \\
$3 \%$ & 0,229 & 0,428 & 0,443 \\
$6 \%$ & 0,295 & 0,365 & 0,478 \\
$9 \%$ & 0,397 & 0,388 & 0,591 \\
$12 \%$ & 0,408 & 0,406 & 0,611 \\
$15 \%$ & 0,399 & 0,384 & 0,591 \\
\hline
\end{tabular}

Volume 3 No.2, Juni 2021

e-ISSN 2775-4529

p-ISSN 2775-8613

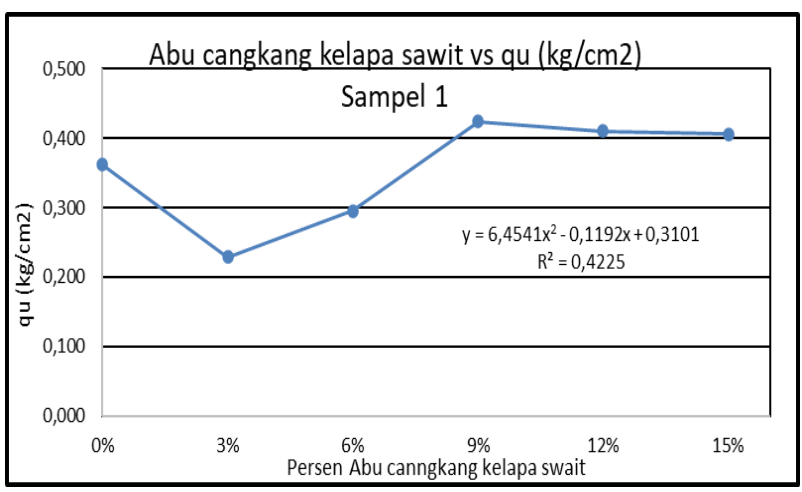

Gambar 6. Grafik abu cangkang kelapa sawit terhadap qu $(\mathrm{kg} / \mathrm{cm} 2)$ titik 1

Pada Sampel 1 pencampuran tanah dan abu cangkang kelapa sawit menunjukkan nilai kuat tekan (qu) menurun dari $0 \%$ dan meningkat saat penambahan abu cangkang kelapa sawit dengan penambahan $9 \%$, kemudian mengalami menurun saat penambahan abu cangkang kelapa sawit $12 \%$ dan $15 \%$.

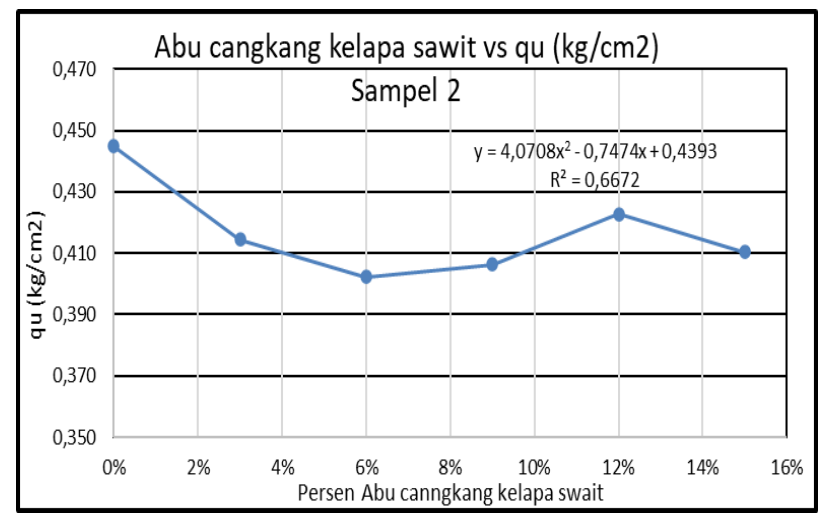

Gambar 7. Grafik abu cangkang kelapa sawit terhadap qu $(\mathrm{kg} / \mathrm{cm} 2)$ titik 2

Sedangkan pada sampel 2 pencampuran tanah pada abu cangkang kelapa sawit menunjukkan nilai kuat tekan (qu) menurun dari $0 \%$ hingga $9 \%$. Namun meningkat saat pencampuran abu cangkang kelapa sawit pada presentase $12 \%$.

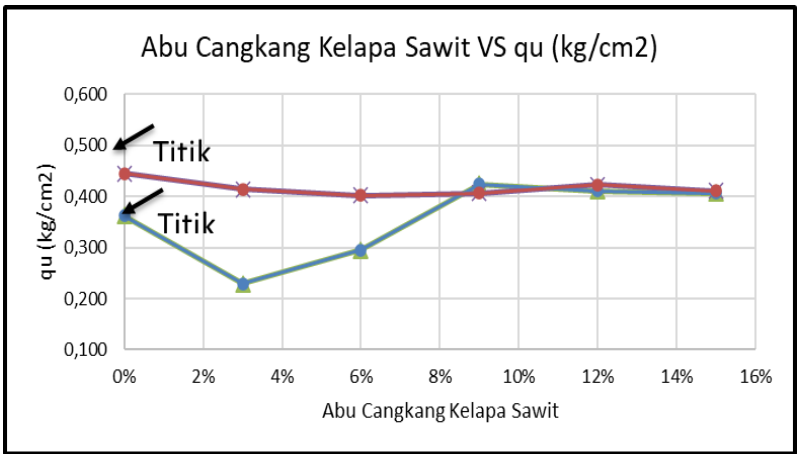


Paulus Civil Engineering Journal

Jurnal Teknik Sipil UKI-Paulus Makassar

https://doi.org/10.52722/pcej.v3i2.3210

\section{Gambar 8. Grafik abu cangkang kelapa sawit terhadap qu $(\mathrm{kg} / \mathrm{cm} 2)$}

Sehingga jika di rata-ratakan semua titik sampel menunjukkan nilai kuat tekan (qu) pada pencampuran tanah dan abu cangkang kelapa sawit menurun dari persentase $0 \%$ namun ada juga kecenderungan peningkatan nilai tegangan kuat tekan bebas (qu) pada persentase campuran abu cangkang kelapa sawit 9\% dan 12\%. Hal ini disebabkan oleh reaksi abu cangkang kelapa sawit yang terkandung dalam tanah dengan kandungan mineral aktif, sehingga dapat bereaksi yang menyebabkan tanah menjadi lebih keras, lebih padat dan stabil. Dimana kandungan air di dalam tanah semakin berkurang dan menjadi keras saat ditambah kadar pencampuran abu cangkang kelapa sawit.

Menurut USCS tanah termasuk berbutir halus pada titik 1 dan 2 karena titik 1 dan 2 persen lolos saringan 200 lebih dari $50 \%$, dan batas cair pada titik 1 kurang dari $50 \%$ dan titik 2 lebih dari $50 \%$. Nilai Indeks Plastisitas pada titik 1 dan 2 di peroleh $7-17 \%$ yang berarti mempunyai sifat plastis sedang.

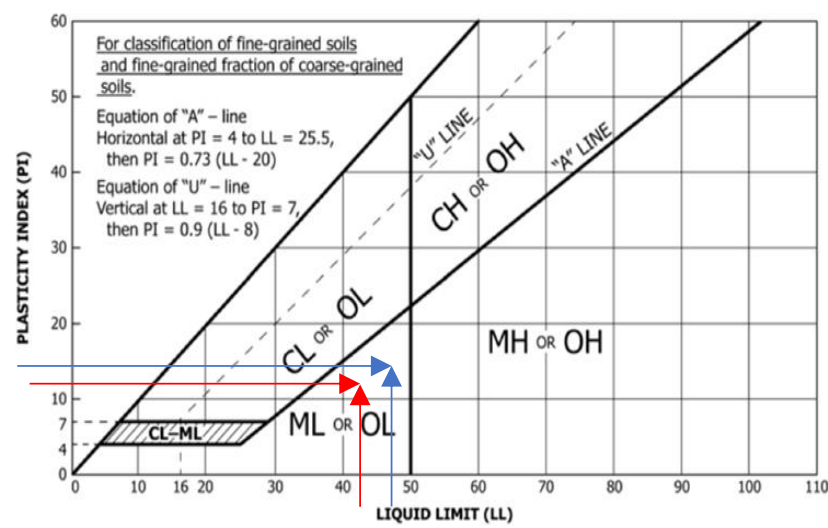

Gambar 9. Grafik Plasticity Chart

Keterangan : $\longrightarrow$ Titik 1

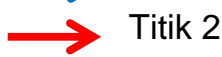

Hubungan potensi pengembangan tanah lempung pada tiap titik dengan indeks plastisitasnya juga dapat diidentifikasi yaitu tanah mempunyai potensi pengembangan rendah karena nilai indeks plastisitas masuk pada interval $0-15 \%$ sehingga dapat diketahui potensi pengembangannya. Dari grafik plasticity chart diatas tanah yang diuji ini tergolong $\mathrm{MH}$ atau $\mathrm{OH}$ dengan kategori tanah lenau atau lempung organic dengan tingkat kompresibilitas tinggi.
Volume 3 No.2, Juni 2021

e-ISSN 2775-4529

p-ISSN 2775-8613
Klasifikasi tanah menurut AASTHO, Pengujian batas-batas Atterberg yang terdiri dari $\mathrm{PL}=$ $37,445 \%, \quad L L=51,165 \%$, dan $I P=13,72 \%$. Pengujian gradasi Analisa saringan dan Hidrometer, dimana persen lolos saringan No.200 sebesar 92,690\%. Maka dari klasifikasi tanah menurut AASTHO menunjukkan sampel tanah tergolong A-7-5 dengan tipe material yang pokok umumnya tanah berlempung.

Hasil pengujian dari kuat tekan bebas dengan penambahan abu cangkang kelapa sawit didapatkan hasil berdasarkan Tabel 17 dan Gambar 11. Hasil Pengujian Kuat Tekan Bebas dan Grafik Abu Cangkang Kelapa Sawit TERHADAP qu $(\mathrm{kg} / \mathrm{cm} 2)$ pada titik 1 mengalami penurunan dari $0 \%$ sebesar 0,362 dan mengalami peningkatan pada penambahan abu cangkang kelapa sawit dari $6 \%$ sebesar 0,295 hingga 9\% sebesar 0,397 , namun menurun pada $12 \%$ sebesar 0,408 dan $15 \%$ sebesar 0,399 .

Sedangkan pada titik 2 juga mengalami penurunan pada persentase $0 \%$ sebesar 0,445 hingga $9 \%$ sebesar 0,406 dan mengalami peningkatan pada $12 \%$ sebesar 0,423 , namun mengalami penurunan pada $15 \%$ sebesar 0,410 .

Dari pengujian ini menunjukan bahwa dari masingmasing sampel tanah dengan campuran abu cangkang kelapa sawit dapat meningkatkan kuat tekan (qu) dari setiap sampel karena abu cangkang kelapa sawit memiliki kemampuan untuk mengikat dan menyerap air sehingga tanah yang tercampur abu cangkang kelapa sawit menjadi padat.

\section{KESIMPULAN}

Sampel tanah dari Paccinongang, Kabupaten Gowa menurtut USCS merupakan tanah dan menurut AASTHO termasuk dalam kelompok A-7-5.

Dari pengujian Kuat Tekan Bebas (Unconfined Compression Test) pada tanah lempung Paccinongang, Kabupaten Guwa dengan penambahan abu cangkang kelapa sawit dari kedua sampel terjadi peningkatan pada penambahan $9 \%$ dan $12 \%$ dari tanah lempung normal.

DAFTAR PUSTAKA 
[1] Braja M Das, 1993, "Sifat-Sifat Fisis dan Geoteknis Tanah (Mekanika Tanah), Erlangga, Jakarta

[2] Sarifah J., dan Pasaribu B, 2017, "Pengaruh Penggunaan Abu Cangkang Kelapa Sawit Guna Meningkatkan Stabilitas Tanah Lempung", Buletin Utama Teknik, Volume. 13, Nomor. 1, HIm. 55-60

[3] Gaudensius N Pait, 2013, "Stabilisasi Tanah", Malang : Universitas Merdeka Malang.

[4] Endriani D, 2012, "Pengaruh Penambahan Abu Cangkang Sawit Terhadap Daya Dukung dan Kuat Tekan pada Tanah lempung ditinjau dari UCT Dan CBR Laboratorium". Skripsi Teknik Sipil. Universitas Sumatra Utara. Medan.

[5] Hardiyatmo, H. C, 1992. "Mekanika Tanah Jilid I". Gramedia Pustaka Umum.

[6] Sudarmo, G.D., Purnomo, S.J.E, 1997. "Mekanikan Tanah I". Penerbit Kanisius,
Yogyakarta.

[7] Bowles, Joseph.E, 1993. "Sifat-Sifat Fisis dan Geoteknis Tanah (Mekanika Tanah)". Erlangga, Jakarta

[8] Sinaga, Hasoloan H.P, 2014, "Pengujian Kuat Tekan Bebas (Unconfined Compression Test) Pada Stabilitas Tanah Lempung Dengan Campuran Semen dan Abu Cangkang Kelapa Sawit", J. Tek. Sipil USU., Volume 13. Nomor 2.

[9] D. M. Pangandongan, R. Rachman and I. L. K. Wong, 2020, "Pengaruh Penambahan Bubuk Gypsum Pada Tanah Lempung Terhadap Uji California Bearing Ratio (CBR)," Paulus Civil Engineering Journal, vol. 2, no. 4, pp. 263-272.

[10] Shirley LH, 1987. "Geoteknik dan Mekanika Tanah", Penerbit Nova. Bandung.

[11] Grim, Ralph E. 1953. "Clay Mineralogy”. New York. McGraw-Hill 